\title{
PENGARUH NIKAH DI BAWAH TANGAN TERHADAP PSIKOLOGIS ISTRI DAN ANAK
}

\author{
Novita Friska ${ }^{1}$, Cut Latifah ${ }^{2}$ \\ Universitas Muslim Nusantara (UMN) Al-Washliyah \\ Jl. Garu II No. 93Medan
}

\begin{abstract}
Abstrak
Perkawinan adalah ikatan lahir bathin antara seorang laki-laki dan seorang perempuan sebagai suamiistri dengan tujuan membentuk keluarga (rumah tangga) yang bahagia dan kekal berdasarkan Ketuhanan Yang Maha Esa. Perkawinan merupakan bagian yang sakral karena harus melihat normanorma dan kaidah hidup dalam masyarakat. Namun dalam hal ini tidak semua orang memiliki prinsip demikian, dengan berbagai alasan pembenaran yang cukup masuk akal dan bisa diterima masyarakat, perkawinan sering kali tidak dihargai kesakralannya. Pernikahan merupakan sebuah media yang akan mempersatukan dua insan dalam sebuah rumah tangga. Pernikahan adalah satu-satunya ritual pemersatu dua insan yang diakui secara resmi dalam hukum kenegaraan maupun hukum agama. Seorang laki-laki yang menikahi perempuan dengan cara nikah di bawah tangan bisa saja dengan seenaknya meninggalkan istri tanpa dibebani tanggung jawab apapun terhadap istri dan anaknya karena tidak adanya bukti otentik dalam pernikahannya, terbukanya peluang bagi laki-laki untuk melakukan tindakan KDRT (Kekerasan Dalam Rumah Tangga), terhalangnya pembagian warrisan dan hak nafkah. Kesulitan untuk membuat akte kelahiran anak karena tidak ada bukti otentik bahwa pernikahan tersebut sah menurut hukum negara, dampak psikis tentunya akan dirasakan oleh anakanak, yang tidak jarang dari mereka menjadi topik pembicaraan masyarakat yang menganggapnegatif perkawinan orang tuanya yang tidak dicatatkan dan masih banyak lagi dampak yang ditimbulkan
\end{abstract}

Kata Kunci : Doulu, Akta Nikah, KDRT

\begin{abstract}
Marriage is a mental bond between a man and a woman as a husband and wife with the goal of forming a happy and eternal family (household) based on the One Supreme Godhead. Marriage is a sacred part because it must see the norms and rules of life in society. But in this case not all people have such a principle, for various reasons justification that is quite reasonable and acceptable to society, marriage is often not appreciated its sanctity. Marriage is a medium that will unite two people in a household. Marriage is the only unifying rite of two persons officially recognized in both state law and religious law. A man who marries a woman under the marriage under the hands may simply leave his wife unencumbered with any responsibility to his wife and children in the absence of authentic evidence in his marriage, the opening of opportunities for men to commit domestic violence (Domestic Violence Ladders), obstruction of division of warrisan and livelihood rights. The difficulty of making a child's birth certificate because there is no authentic proof that the marriage is legal under the law of the state, the psychic impact will certainly be felt by the children, which is not uncommon of them become the topic of public discussion that considers the negatives of unposted parents and many more impacts
\end{abstract}

Keywords: Doulu, Marriage Certificate, Domestic Violence 


\section{PENDAHULUAN}

Perkawinan adalah ikatan lahir bathin antara seorang laki-laki dan seorang perempuan sebagai suami-istri dengan tujuan membentuk keluarga (rumah tangga) yang bahagia dan kekal berdasarkan Ketuhanan Yang Maha Esa. Perkawinan merupakan bagian yang sakral karena harus melihat norma-norma dan kaidah hidup dalam masyarakat. Namun dalam hal ini tidak semua orang memiliki prinsip demikian, dengan berbagai alasan pembenaran yang cukup masuk akal dan bisa diterima masyarakat, perkawinan sering kali tidak dihargai kesakralannya. Pernikahan merupakan sebuah media yang akan mempersatukan dua insan dalam sebuah rumah tangga. Pernikahan adalah satu-satunya ritual pemersatu dua insan yang diakui secara resmi dalam hukum kenegaraan maupun hukum agama.

Banyaknya keluarga di Desa Doulu Kecamatan Berastagi yang belum memiliki akta nikah merupakan suatu masalah yang besar, hal ini dikarenakan masih banyak masyarakat yang belum memahami betapa pentingnya akta nikah untuk kehidupan yang akan datang. Mereka juga tidak mengetahui bahwa kaum wanita dan anakanak dapat menjadi korban jika mereka tidak memiliki akta nikah, ini akan menjadi beban psikis bagi keduanya. Bagi kaum wanita hal ini dapat memicu terjadinya kekerasan dalam rumah tangga, sedangkan bagi anak hal ini dapat menjadi bahan olokan di masyarakat bahwa anak tersebut terlahir sebagai anak haram dan juga anak akan susah untuk mengurus akta kelahiran karena tidak adanya bukti yang otentik. Ini akan sangat mengganggu tumbuh kembang anak tersebut, baik di lingkungan sekolah maupun lingkungan masyarakat.

\section{METODE PELAKSANAAN}

\section{Pelaksanaan Ipteks Bagi}

Masyarakat ini disampaikan melalui kegiatan dialog interaktif dan tanya jawab tentang "Pengaruh Nikah Di bawah Tangan Terhadap Psikologis Istri Dan Anak".
Dalam rangka kegiatan pengabdian ini, Pemerintah Desa Doulu Kecamatan Berastagi bersedia menyediakan tempat pelaksanaan dan juga menyediakan sarana pendukung lainnya yang diperlukan selama kegiatan berlangsung.

\section{HASIL DAN PEMBAHASAN}

Hasil dan luaran yang dihasilkan dari kegiatan ini secara umum adalah masyarakat dapat memahami betapa pentingnya pasangan suami istri memiliki akta nikah, selain sebagai dokumen penting pada pemerintah akta nikah juga sangat penting untuk memberikan keabsahan atas adanya pernikahan dan memudahkan birokrasi, selain itu juga akta nikah dibuat untuk memastikan istri bisa mendapatkan haknya baik dalam bentuk materi maupun secara psikologis.

Sedangkan luaran yang dicapai dari pengabdian ini adalah pengabdian ini akan di publikasikan dalam Jural ber ISSN. Dalam pengabdian masyarakat ini, rencana tahapan berikutnya yang akan dilakukan adalah memberikan penyuluhan dengan judul yang sama pada tempat atau daerahdaerah lain yang masyarakatnya masih minim pengetahuan tentang pentingnya akta nikah, jika memang diperlukan pengabdian ini rencananya akan dilanjutkan pada pengabdian hibah dikti.

\section{KESIMPULAN}

Kesimpulan dari kegiatan pengabdian di Balai Desa, Desa Doulu Kecamatan Berastagi ini adalah masyarakat lebih terbuka dan mau diajak sharing mengenai pengetahuan betapa pentingnya sebuah keluarga khususnya suami istri mencatatkan pernikahannya di pemerintahan sehingga memiliki akta nikah. Karena hal ini akan besar pengaruhnya terhadap psikologis anak dan istri, dan pada akhirnya masyarakat juga sadar dan paham tentang pentingnya memiliki akta nikah.

\section{DAFTAR PUSTAKA}


Amaliyah: Jurnal Pengabdian Kepada Masyarakat Volume 1 No. 1 Mei 2017

Ch, Mufidah. Psikologi Keluarga Islam Berwawasan Gender. Malang: UIN Malang

Press, 2008.

Jahja, Yudrik. Psikologi

Perkembangan. Jakarta: Kencana, 2011.

Mudzhar, M. Atho, S. Alvi, Sajida, Sadli, dan Saparinah, ed. Wanita Dalam Masyarakat Indonesia Akses, Pemberdayaan, dan Kesempatan. Yogyakarta: Sunan Kalijaga Press 